\title{
チゲサイクリンによる皮膚障害を呈した日本人症例
}

\author{
坂倉広大* ${ }^{*}$ 中蔵伊知郎, 今西嘉生里, 佐光留美, 土井敏行, 山㟝邦夫 \\ 国立病院機構 大阪医療センター 薬剤部
}

\section{Occurrence of Drug Eruption following Tigecycline Treatment in a Japanese Patient}

\author{
Kota Sakakura*, Ichiro Nakakura, Kaori Imanishi, Rumi Sako, Toshiyuki Doi and Kunio Yamazaki \\ Department of Pharmacy, Osaka National Hospital \\ $\left[\begin{array}{l}\text { Received June 13, } 2017 \\ \text { Accepted November 14, } 2017\end{array}\right]$
}

Tigecycline (TGC) is a glycylcycline antibiotic that arises from the cooperation of the t-butylglycylamido in position 9 of minocycline and is used to treat various bacterial infections. Side effects such as rash, itching, and other severe drug eruption have all been reported outside of Japan; however, symptomatic treatment of Japanese patients with TGCrelated drug eruption is not well studied. Here, we present the first report on the symptomatic treatment of drug eruption in a TGC-treated Japanese patient. A man in his 70 s with liver abscess, caused by metallo- $\beta$-lactamase producing Escherichia coli, was treated with TGC. On day 10 post-treatment, erythema accompanied by itching occurred on the back, precordium, cervix, and upper limb. As the irritation could be TGC-related, the treatment was discontinued and replaced with injectable hydrocortisone, oral fexofenadine, and topical corticosteroids. Following the symptomatic treatment, symptoms of erythema and itching showed improvement. This case report described the occurrence of drug eruption in a Japanese patient following TGC treatment was observed in Japanese patients as well, and discontinuing the TGC treatment and providing symptomatic treatment might be an effective therapy in such cases. In addition, the drug eruption caused by TGC improved at a much slower rate after discontinuing the respective treatments.

Key words — tigecycline, side effect, drug eruption, Japanese patient, steroid

\section{緒言}

チゲサイクリン（tigecycline: TGC）は, ミノサ イクリン（minocycline: MINO）の9位をグリシル アミド基に置換させたグリシルサイクリン系抗菌薬 である，その抗菌スペクトルは広域であり，メチシ リン耐性黄色ブドウ球菌を含むグラム陽性菌, 多 剂耐性グラム陰性菌, 偏性嫌気性菌そして非定型 菌へ活性を示す. ${ }^{1)}$ US Food and Drug Administration から報告されている主な有害事象は, 悪心, 嘔吐, 下痢を主症状とした消化器症状であるが, 皮膚有 害事象として発疹も報告されている（https://www. accessdata.fda.gov/drugsatfda_docs/label/2010/ 021821s021lbl.pdf，2017 年 2 月 18 日)。また，イ ンタビューフォームには, 海外において実施され た第 3 相試験および市販後安全性情報に基づいて 発疹, 掻痒感, 重症皮膚反応が記載されている（夕 イガシル ${ }^{\circledR}$ 点滴静注用 $50 \mathrm{mg}$, ファイザー株式会 社, 2015 年 9 月 改訂 第 4 版). しかし, 日本人 に対する臨床試験データの記載はなく, 症状の程 度および対症療法の詳細は不明である。今回, TGCにより皮膚有害事象が出現し, TGCの投与 中止および一般的な対症療法により効果を示した 日本人症例を経験したので報告する。なお, 本症 例報告は,「個人情報の保護に関する法律」に従い, 患者プライバシーに十分配慮したうえで行った。

\footnotetext{
* $=540-0006$ 大阪市中央区法円坂2-1-14
} 


\section{症例}

70 歳代, 男性. 入院後, 十二指腸乳頭部がん, 総胆管結石および胆囊結石に対し亜全胃温存膵頭 十二指腸切除が施行された。術後にはウインス ロー孔，膵臓上縁および下縁のドレーン排液より Enterococcus faecalis が検出された，術後合併症と して，胆管炎，肺炎および腹腔内感染に対する治 療を継続していた。術後 196 日目に悪寒を伴う $38.3^{\circ} \mathrm{C}$ の発熱を生じ， 経験的治療としてスルバク タム/アンピシリン (sulbactam/ampicillin: SBT/ ABPC) $1.5 \mathrm{~g} 8$ 時間毎で治療が開始された。血液 培養より Bacteroides fragilis が検出され, 腹部 CT より液貯留を肝右葉に認めた。肝膿瘍が疑われ, 経皮経肝膿瘍ドレーンが留置された。肝膿瘍ドレ ナージ検体から Bacteroides fragilis および metallo- $\beta$ lactamase（MBL）産生 Escherichia coli が検出さ れた。膿瘍は縮小し肝膿瘍ドレナージは良好と判 断され，熱型も安定したことから術後213日目に SBT/ABPC は一旦終了された。しかし，翌日に $39.1^{\circ} \mathrm{C}$ の悪寒を伴う発熱が出現した。このため, 術 後 214 日目に Bacteroides fragilis に対してセフメタ ゾール (cefmetazole: CMZ) $1 \mathrm{~g} 8$ 時間毎が開始され た。 また, MBL 産生 Escherichia coli も治療の対象 とし, 感受性のあったスルファメトキサゾール / ト リメトプリム (sulfamethoxazole/trimethoprim: ST) 合剂 $4 \mathrm{~g}$ / 日（配合顆粒，1 日 2 回，朝夕食後）の投 与が開始された。なお，MBL 産生 Escherichia coli の薬剂感受性結果は, 表 1 に示した.

術後 216 日目に解熱し, 術後 228 日目にCMZ およびST 合剤の投与は終了された，術後 230 日 目に $38.6^{\circ} \mathrm{C}$ の発熱を認め, 肝膿瘍ドレーン排液よ り検出された Candida glabrataに対してミカファ ンギン（micafungin: MCFG）150 mg 24 時間毎に よる治療が 5 日間行われた。しかし，術後 235 日 目に再び $38.5^{\circ} \mathrm{C}$ の発熱を認めたためメロペネム (meropenem: MEPM) $2 \mathrm{~g} 8$ 時間毎, ST 合剤 $4 \mathrm{~g} /$ 日 (配合顆粒，1 日 2 回，朝夕食後）および MCFG による治療が 5 日間行われた。この治療による改 善を認めなかったため, 術後 240 日目にST 合剤 から $\mathrm{TGC}$ 初回のみ $100 \mathrm{mg}$, 以後 $50 \mathrm{mg} 12$ 時間毎 へ変更し, MEPM および TGCによる併用療法と
表 1 検出された MBL 産生 Escherichia coli の感受性

\begin{tabular}{lcc}
\hline \hline \multicolumn{1}{c}{ 抗菌薬名 } & $\mathrm{MIC}, \mu \mathrm{g} / \mathrm{mL}$ & $\mathrm{S}, \mathrm{I}, \mathrm{R}$ \\
\hline アンピシリン & $\geqq 32$ & $\mathrm{R}$ \\
ピペラシリン & $\geqq 128$ & $\mathrm{R}$ \\
セファゾリン & $\geqq 32$ & $\mathrm{R}$ \\
セフォチアム & $\geqq 32$ & $\mathrm{R}$ \\
セフタジジム & $\geqq 64$ & $\mathrm{R}$ \\
メロペネム & $\leqq 1$ & $\mathrm{R}$ \\
アミカシン & $\leqq 4$ & $\mathrm{~S}$ \\
ミノサイクリン & $=4$ & $\mathrm{~S}$ \\
スルバクタム/アンピシリン & $\geqq 32$ & $\mathrm{R}$ \\
セフメタゾール & $\geqq 64$ & $\mathrm{R}$ \\
セフェピム & $\geqq 32$ & $\mathrm{R}$ \\
スルバクタム/セフォペラゾン & $\geqq 64$ & $\mathrm{R}$ \\
アズトレオナム & $\geqq 32$ & $\mathrm{R}$ \\
レボフロキサシン & $\geqq 8$ & $\mathrm{R}$ \\
シプロフロキサシン & $\geqq 8$ & $\mathrm{R}$ \\
スルファメトキサゾール / & - & $\mathrm{S}$ \\
トリメトプリム & - & $\mathrm{I}$ \\
ゲンタマイシン & - & $\mathrm{R}$ \\
トブラマイシン & &
\end{tabular}

薬剂感受性試験は, BD Phoenix Automated Microbiology System により行った. ブレイクポイントは, Clinical and Laboratory Standards Institute guidelines, M100-S22を使用した. メロペ ネムの感受性に関して, MBL 産生菌であるため, 表記は, R となっている. MBL: metallo- $\beta$-lactamase, MIC: minimum inhibitory concentration, I: intermediate, R: resistant, S: susceptible.

なった，TGC 投与開始前の所見は，身長 $159 \mathrm{~cm}$, 体重 $45 \mathrm{~kg}$. 投与前日からの臨床検査值の経過は, 表 2 に示す. TGC の投与開始時に併用されていた 薬剤は，アムロジピンベシル酸塩錠，シルニジピ ン錠，耐性乳酸菌製剂，ランソプラゾール口腔内 崩壊錠，大建中湯，D-ソルビトール，ミアンセリ ン塩酸塩錠,ニトラゼパム錠であった。これらの 併用薬剂は，半年以上前より服用されていた. TGC 投与開始初期において, TGC の主な副作用と されている消化器症状やその他の症状 ${ }^{2)}$ 認めず 経過していた。しかし, 投与 10 日目に背部, 前胸 部, 前額部, 頸部および両上肢に掻痒感を伴う蕁 麻疹様紅斑を認めた。熱発を生じ，最高温度は $39.3^{\circ} \mathrm{C}$ まで上昇したが，脈拍は 95 拍/分で比較的 徐脈 $^{3)}$ であった。血液培養を採取のうえ, 全身性 の掻㾕感を伴う発疹の被疑薬として TGC の投与を 中止し, 同日よりヒドロコルチゾン $100 \mathrm{mg}$ を単回 静脈投与およびフェキソフェナジン錠 $120 \mathrm{mg} /$ 日 （1 日 2 回, 朝夕食後）の定期内服が開始された. しかし，血液検査は行われなかった。 なお，同日に 提出された血液培養は院性であった。点滴静注後, 
表 2 臨床検查值の経過

\begin{tabular}{|c|c|c|c|c|c|}
\hline & $\begin{array}{l}\text { 皮膚障害発現 } \\
11 \text { 日前（TGC } \\
\text { 投与開始前日） }\end{array}$ & $\begin{array}{c}\text { 皮膚障害発現 } \\
3 \text { 日前（TGC } \\
\text { 投与開始 } 8 \text { 日目） }\end{array}$ & $\begin{array}{c}\text { 皮膚障害発現 } \\
3 \text { 日後 (TGC } \\
\text { 投与中止 } 3 \text { 日目) }\end{array}$ & $\begin{array}{c}\text { 皮膚障害改善日 } \\
\text { (TGC 投与中止 } \\
7 \text { 日目) }\end{array}$ & $\begin{array}{c}\text { 皮膚障害消失日 } \\
\text { (TGC 投与中止 } \\
17 \text { 日目) }\end{array}$ \\
\hline AST（IU/L） & 25 & 32 & 47 & 35 & 82 \\
\hline ALT（IU/L） & 25 & 24 & 30 & 27 & 54 \\
\hline T-Bil（mg/dL） & 0.1 & 0.2 & 0.2 & 0.2 & 0.3 \\
\hline$\gamma$-GTP $($ IU/L $)$ & 34 & - & - & - & - \\
\hline Alb $(\mathrm{g} / \mathrm{dL})$ & 1.9 & 2 & 1.8 & 1.5 & 2.8 \\
\hline $\mathrm{SCr}(\mathrm{mg} / \mathrm{dL})$ & 0.76 & 0.54 & 0.55 & 0.54 & 0.51 \\
\hline CRP ( $\mathrm{mg} / \mathrm{dL})$ & 7.64 & 1.64 & 2.17 & 1.96 & 1.65 \\
\hline $\mathrm{WBC}(/ \mu \mathrm{L})$ & 8,600 & 9,600 & 8,900 & 13,100 & 8,300 \\
\hline Lymp $(/ \mu \mathrm{L})$ & 4,100 & 4,300 & 3,100 & 3,500 & 2,900 \\
\hline $\operatorname{Eos}(/ \mu \mathrm{L})$ & 200 & 600 & 2,400 & 5,400 & 2,000 \\
\hline Aty-Lym (\%) & - & 3.7 & - & - & 0.5 \\
\hline $\mathrm{Hb} \quad(\mathrm{g} / \mathrm{dL})$ & 8.6 & 9.7 & 10.3 & 10.6 & 10.5 \\
\hline $\operatorname{PLT}(/ \mu \mathrm{L})$ & 350,000 & 307,000 & 276,000 & 277,000 & 285,000 \\
\hline
\end{tabular}

TGC: チゲサイクリン, AST: アスパラギン酸アミノ基転移酵素, ALT: アラニンアミノ基転移酵素, T-Bil: 総ビリルビン值, $\gamma$-GTP: $\gamma$-グルタミルトランスペプチターゼ, Alb: アルブミン值, SCr: 血清クレアチニン值, CRP:C 反応性タンパク, WBC: 白血球数, Lymp: リンパ球数, Eos: 好酸球数, Aty-Lym: 異型リンパ球, Hb: モモグロビン值, PLT: 血小板数

紅斑は軽減し掻痒感も軽快した。加えてクーリング

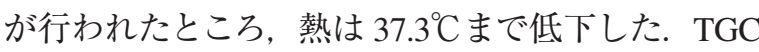
の投与中止 2 日目，掻痒感は治まった。しかし，顔 面の紅斑に関しては, 改善を認めたものの, 背部, 前胸部，頸部および両上肢の紅斑について改善は しなかった，TGC の投与中止 3 日目，ステロイド外 用剤（顔面はアルクロメタゾン酸プロピオンエステ ル，それ以外はベタメタゾン酪酸エステルプロピオ ン酸エステル）が追加され, MBL 産生 Escherichia coli の治療を目的にアミカシン硫酸塩 $600 \mathrm{mg} 48$ 時 間毎が開始された．同日の好酸球数は，2,400/ $/ \mathrm{L}$ （27\%）であった. TGC の投与中止 7 日目に皮膚 障害は改善を認め, 17 日目に消失した，好酸球数 は， TGC 投与中止 7 日目に $5,400 / \mu \mathrm{L}(41.1 \%)$ ま で上昇し，皮膚障害の消失した TGC 投与中止 17 日目に $2,000 / \mu \mathrm{L} （ 24.2 \%)$ まで低下した. TGC 投 与中止 21 日目には, 当院基準值内 $900 / \mu \mathrm{L}$ (6.9\%) となった（図 1)。しかしながら，TGC 投与前の好 酸球数であった $200 / \mu \mathrm{L}$ に低下するまでに，最終 的に 93 日間を要した。皮膚障害消失後, 再発は 認められていない．ヒトヘルペスウイルス 6 に代 表されるようなウイルス性発疹症検査は行ってい ないものの皮膚障害発現時およびそれ以後もリン パ球および異型リンパ球の上昇は観察されなかっ た（図 1)。また，本症例で脳症，腹水，リンパ節 腫大, 多臓器障害はなかった。

\section{考察}

本症例は，日本人においても TGCによる皮膚 有害事象が確認された初めての報告である。臨床 所見においても2 点の有益な点が観察された。 1 点は, 皮膚障害出現時の一般的な対症療法である ステロイド静注薬, 経口抗アレルギー薬およびス テロイド外用剤が有効であった。 もう 1 点は, 皮 膚障害の遷延が認められた。

TGC 投与後に一般的な副作用である消化器症状 は認めなかったが, TGCによる掻痒感を伴う皮虐 障害が出現したものと考えられた。皮膚障害発生 時の服用薬は, いずれも 6 力月以上前から服用さ れており， MEPMに関しても TGC の投与中止後も 継続されたが, 対症療法により症状は改善された。 このため, TGC 使用時に併用された薬剤に関して は, 皮膚障害の被疑薬である可能性は低いと考え られる。 また, 血流感染による発疹は, 皮膚障害出 現時の血液培養は陰性であり, 否定的であった。

US Food and Drug Administrationの報告による と, 海外の臨床試験の集積データより掻痒感の頻 度は, 3\%である（https://www.accessdata.fda.gov/ drugsatfda_docs/label/2010/021821s021lbl.pdf, 2017 年 2 月 18 日). 中国人のみを対象にした臨床試験で

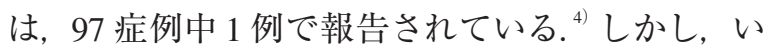
ずれの報告も皮膚障害の経過や対処に関して, 詳 


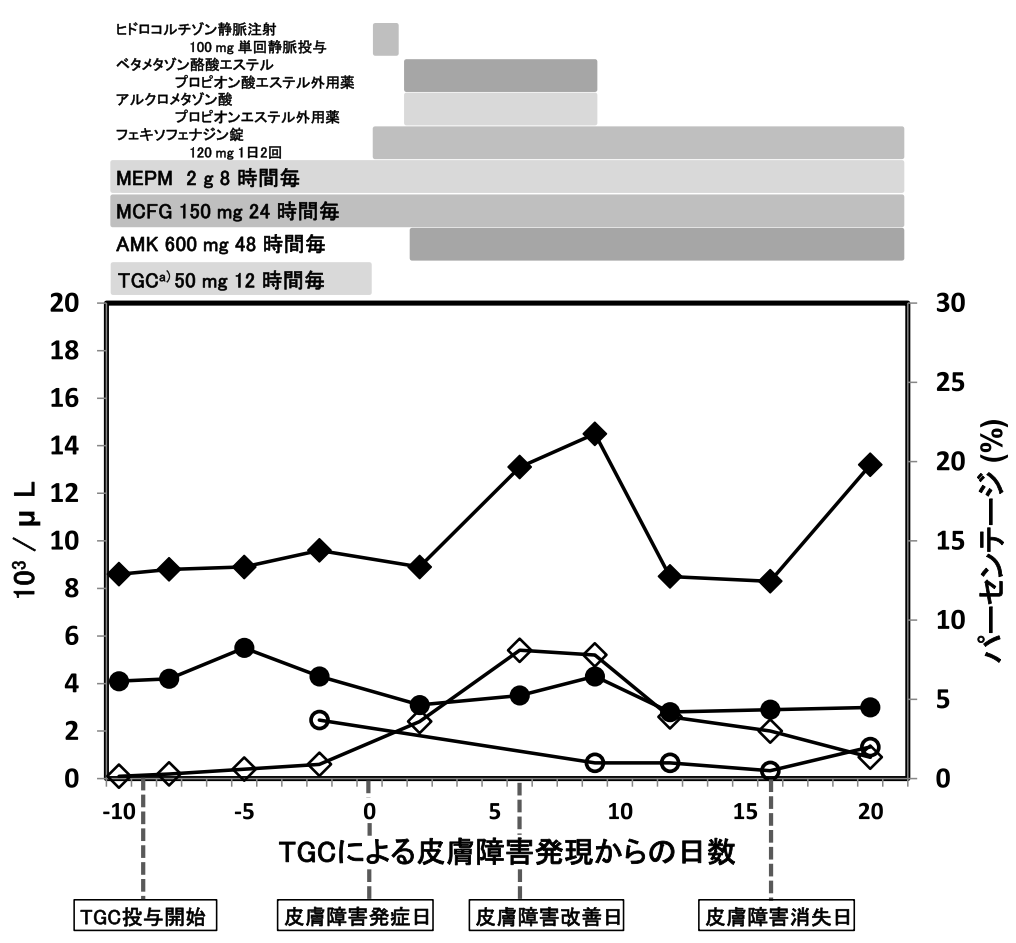

図 1 皮膚障害発現前後の白血球数, リンパ球数, 好酸球数および異型リンパ球のパーセンテージおよび使用薬 剂の経過表

a）初回量のみ $100 \mathrm{mg}$. 横軸は, TGCによる皮膚障害が発現した日を 0 日とし，経過前後の日数を示している. TGC: チゲサイクリン， AMK: アミカシン, MEPM: メロペネム, MCFG: ミカファンギン, 白血球数 $\left(10^{3} / \mu \mathrm{L}\right)$ リンパ球数 $\left(10^{3} / \mu \mathrm{L}\right) \diamond$ 好酸球数 $\left(10^{3} / \mu \mathrm{L}\right)$ 異型リンパ球（\%)

細は報告されていない，また，筆者らが調べた限り， TGCによる皮膚障害に関して，人種差に言及した 報告はなかった。本症例は，皮膚障害の改善まで に7日間，消失までにその後 10 日間を要した。 $\mathrm{TGC}$ は，健常人に対し $50 \mathrm{mg}$ を 12 時間毎に投与し た際の血中半減期は 36.9 時間であり, ${ }^{5}$ 健常人であ れば，理論上 ${ }^{6}$ 約 185 時間，約 7 日間で血中から消 失すると考えられる。しかし，皮膚障害の消失まで にさらなる時間を要した，TGCのクリアランスに関 して，腎障害，年齢および性別においては影響を受 けないが肝障害では影響を受けることが知られてい る. ${ }^{7-9)}$ 肝障害に関しては, Child-Pugh スコア B 以上 でクリアランスが低下すると報告されている.9 本報 告では，後方視的調査であり，プロトロンビン時間 のデータが久損しているため Child-Pugh スコアを 算出することができなかった，しかし，皮膚障害発 現日から消失日までの間，アルブミン值は $2.8 \mathrm{~g} / \mathrm{dL}$ 以下であったため，少なくとも Child-Pugh スコアは B 以上であることが考えられた。 よって，TGCの肝 クリアランスの低下も要因の 1 つとして考えられた. ほかに考慮すべき要因として TGC の組織移行性が
高いことが挙げられた. ${ }^{10,11)}$ TGC 投与 5〜 7 時間後の 皮膚組織に扔ける TGC 濃度は, 血清における TGC

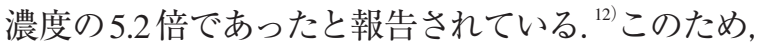
投与中止後も組織に薬物が滞留し, 皮膚障害消失 が遷延した要因の1つとして考えられた。

体内滞留以外の皮膚障害の原因㧍よび遷延の要 因として，TGC は MINO と類似構造であること から drug-induced hypersensitivity syndrome (DIHS) および drug reaction with eosinophilia and systemic syndrome（DRESS）を疑った. DIHS に関しては, 診断基準の主要所見である肝機能障害やその他の 重篤な臟器障害, リンパ節の腫脹は認められず, ${ }^{13}$ 二峰性の皮膚障害 ${ }^{14)}$ も確認されなかったため, そ の可能性は低いと考えられた。しかし, DRESSに 関しては，その可能性を否定することができな かった，本症例は， TGC 投与中止日の好酸球值を 欠損しているが, TGC 投与開始前日では, 好酸球 值は $200 / \mu \mathrm{L}$ であったが, 皮膚障害発現 3 日前に $600 / \mu \mathrm{L}$, TGC 投与中止 3 日目に $2,400 / \mu \mathrm{L}$ まで上 昇を認めた（図 1，表 2)。TGC 投与中止日が 700 / $\mu \mathrm{L}$ 以上であったと考えると DRESS の診断スコア 


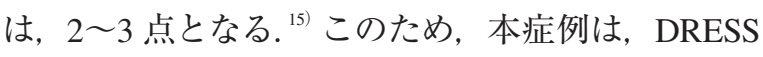
の可能性のある症例に分類されると考えられた. また，好酸球数が長期間安定しなかったことから も TGCによる薬剤アレルギー反応以外の免疫応答 が起きている可能性も考えられた。

以上より，日本人に打いても TGCによる皮膚 有害事象が確認され, 初期治療として, TGC の中 止，一般的な対症療法が有効な手段の 1 つであっ た、しかしながら，本症例で確認された皮膚障害 の遷延に関しては, TGC の肝クリアランスの低下 や TGC の皮膚組織移行性の高さから体内に滞留 していたためであるのか，TGCの薬剤アレルギー が DRESS のような複雑な免疫応答によるもので あるのか判断をつけることができなかった，現在， 国内における TGCの使用頻度が低いことから, 使用経験の報告は非常に限られている. ${ }^{2}$ 今後の症 例の集積により，本症例で確認された皮膚障害の 遷延が，TGCによる皮膚障害において一般的な事 象であるか検討されることが望まれる .

\section{利益相反}

開示すべき利益相反はない.

\section{引用文献}

1) Noskin GA, Tigecycline: a new glycylcycline for treatment of serious infections, Clin Infect Dis, 2005, 41, S303-S314.

2）チゲサイクリン適正使用のための手引き作成委 員会, チゲサイクリン適正使用のための手引き, 化学療法学会雑誌, 2014, 62, 311-366.

3) Cunha BA, The diagnostic significance of relative bradycardia in infectious disease, Clin Microbiol Infect, 2000, 6, 633-634.

4) Chen Z, Wu J, Zhang Y, Wei J, Leng X, Bi J, Li R, Yan L, Quan Z, Chen X, Yu Y, Wu Z, Liu D, Ma X, Maroko R, Cooper A, Efficacy and safety of tigecycline monotherapy vs. imipenem/cilastatin in Chinese patients with complicated intra-abdominal infections: a randomized controlled trial, $B M C$ Infect Dis, 2010, 10, 217, doi: 10.1186/1471-2334-10217.

5) Muralidharan G, Micalizzi M, Speth J, Raible D,
Troy S, Pharmacokinetics of tigecycline after single and multiple doses in healthy subjects, Antimicrob Agents Chemother, 2005, 49, 220-229.

6）灘井雅行, 薬物動態の基礎と薬物投与設計への 応用, 日本小児腎臓病学会雑誌, 2006, 19, 111-123.

7) Meagher AK, Ambrose PG, Grasela TH, EllisGrosse EJ, The pharmacokinetic and pharmacodynamic profile of tigecycline, Clin Infect Dis, 2005, 41, S333-S340.

8) Muralidharan G, Fruncillo RJ, Micalizzi M, Raible DG, Troy SM, Effects of age and sex on single-dose pharmacokinetics of tigecycline in healthy subjects, Antimicrob Agents Chemother, 2005, 49, 1656-1659.

9) Korth-Bradley JM, Baird-Bellaire SJ, Patat AA, Troy SM, Böhmer GM, Gleiter CH, Buecheler R, Morgan MY, Pharmacokinetics and safety of a single intravenous dose of the antibiotic tigecycline in patients with cirrhosis, J Clin Pharmacol, 2011, 51, 93-101.

10) Agwuh KN, MacGowan A, Pharmacokinetics and pharmacodynamics of the tetracyclines including glycylcyclines, J Antimicrob Chemother, 2006, 58, 256-265.

11) Rodvold KA, Gotfried MH, Cwik M, Korth-Bradley JM, Dukart G, Ellis-Grosse EJ, Serum, tissue and body fluid concentrations of tigecycline after a single $100 \mathrm{mg}$ dose, J Antimicrob Chemother, 2006, 58, 1221-1229.

12) Montravers P, Bassetti M, Dupont H, Eckmann C, Heizmann WR, Guirao X, García MS, Capparella MR, Simoneau D, Bodmann KF, Efficacy of tigecycline for the treatment of complicated skin and softtissue infections in real-life clinical practice from five European observational studies, J Antimicrob Chemother, 2013, 68, ii15-ii24.

13) Shiohara $T$, Iijima M, Ikezawa $Z$, Hashimoto $K$, The diagnosis of a DRESS syndrome has been sufficiently established on the basis of typical clinical features and viral reactivations, $\mathrm{Br} J$ Dermatol, 2007, 156, 1083-1084.

14）藤山幹子, 橋本公二, 薬剤性過敏症症候群とHHV-6 の再活性化について, ウイルス, 2009, 59, 23-30.

15) Kardaun SH, Sidoroff A, Valeyrie-Allanore L, Halevy S, Davidovici BB, Mockenhaupt M, Roujeau JC, Variability in the clinical pattern of cutaneous side-effects of drugs with systemic symptoms: does a DRESS syndrome really exist?, Br J Dermatol, 2007, 156, 609-611. 